\title{
Financial Perspective 2007-2013: The Last Version of the Old Model
}

\begin{abstract}
Questions on the strategy of the EU development still are rare in the political discourse in Lithuania. This, of course, is a temporary phenomenon. Direct "physical" participation of our country in the European integration and consolidation processes shall lead to, inescapably, a larger involvement into debates about strategic issues of these developments. The financing of processes facilitating integration is one among them. The article deals with the debates on a new seven-year budgetary framework of the EU, the so-called financial perspective (FP), for the years 2007-2013. The article begins with description of several prominent and specific features of the EU budget formation and structure. Main attention is given to the discussion about the new FP during the period of 2004-2006. As a main financial document of the EU, the FP has provoked more exact definitions of national interests within the EU member states, brought their differences to the surface, forced them to specify their demands towards scale and structure of the budget, and pushed them one more time for the search of a compromise. The analysis of the discussion is summarized by general conclusions.
\end{abstract}

\section{Peculiarities of the EU budget}

The very infrequency of the discussion on the European Union (EU) multi-year budgetary framework or "financial perspective" (FP) - and having it once in seven years - equips it with a significant political and ideological importance. There are also other opportunities for reflecting and focusing attention on problems that have accumulated, thereby intensifying the debate on the strategic issues of the EU's development. But few cases stimulate or have a requirement for finishing the discussion up to the very end - by saying "yes" or "no." The approval of single version of the budget (telling "no" to alternatives) provides clear resolution for the future of seven-years duration, allocating in this way, by assigning finances, relatively modest resources for the common actions not gaining preference of the member states and relatively generous resources to the ones which deserve such support. The seven-year long budgetary structure tells much about what the position is of the EU member states and first of all - its larger member states - with regards to the further Community integration and its directions. If political rhetoric, before

\footnotetext{
* Prof., habil. dr. Jonas Čičinskas is a Head of European Studies Department, Institute of International Relations and Political Science, University of Vilnius. Address: Vokiečių 10, LT-01130 Vilnius, tel.: +370-5-2514142, e-mail: jonas.cicinskas@tspmi.vu.lt
} 
the decision on the FP, takes place then afterwards it will decorate the whole discussion with very different formulations and emphasises.

This "reflection ability" of the EU budget can be the more so pronounced if we pay due regard to its two peculiarities, defined in the founding treaties of the European Community.

Firstly, each year the budget should be balanced, and, secondly, it has to be financed in full by Community's own resources. In other words, the goals defined in the budget cannot be financed, in the case of need, by borrowed resources, as well assurplus of revenue should be transferred to the next year thereby reducing that years' member states' contributions accordingly.

This means that the EU budget cannot be used as a discretionary means of active macroeconomic policy put into action in a fluctuating manner that whenever there is a need to smooth its cyclicality (to cool down when it is heating and to spur it on when it cools down). ${ }^{1}$ Its function, when it is ready, is a fully passive one meant to collect effectively the defined amount of revenue and direct it to the defined areas of economic or other activity. In other words, within the Community budget, it fulfils only small redistributive role by which it influences the allocation of productive resources in member states.

It is to be pointed out also, that while being designed with no anti-cyclical capacity, the budget is not pro-cyclical either. It would be as such only if it would be composed each year, limited by the percentage part of GDP (i.e. it would depend on the amount of GDP in previous year) and, as it is now, would be fully balanced. A budget prepared for the seven year period keeps it from being pro-cyclical, at least partially. More so, due to the orientation towards a longer-term period, the budget to some extent is even anti-cyclical, this being first and mainly for the countries which are relatively large recipients. Lithuania, for example, (and other new member states) receives (shall receive) from the EU budget more than three percent of its GDP and this will tangibly rectify its economic activity and will become a stabilising factor for the Lithuanian economy. But for the donor countries to the contrary; such a levelled out planning of contributions and payments might be pro-cyclical since it does not reduce contributions when the economy is "cooling" and does not increase them when economy is "heating."

\footnotetext{
${ }^{1}$ The categorical content of such a statement is somewhat tempered by the efforts to coordinate the fiscal policy of the member states by the means of the Stability and growth pact, especially through commitment (for the members of the EMU accompanied by sanctions in case of breaking it) to secure the implementation of the principle of a balanced budget with only mild deviation, up to 3 percent of the GDP from the full equilibrium.
} 
Although the budget is made up from its so-called "own resources," ${ }^{2}$ actually only common external tariff and, also agricultural levies, are Community sources, this because they exist due to the implementation of the Common Commercial Policy of the Community. Meanwhile payments of value-added tax and the contribution calculated as a part of gross national income (GNI) are liabilities, established by the common agreement of the participating countries; this is like a particular kind of "membership fee." Even more important is the fact that due to foreign trade liberalization, these two forms of ones "own resources" make up progressively declining part of the budget. ${ }^{3}$ Therefore, the question of genuinely own resources for the Community, which is deepening (or striving to deepen) integration, is being raised more acutely. Already in 1997, the European Commission while presenting the draft financial perspective for 2000-2006, pointed out that "a real modification [of budgetary resources - J.Č.] would be brought about only by the passage to a situation where the whole of the Community budget would be financed by autonomous fiscal resources." ${ }^{4}$

This reduction of the share of own resources, which come to the budget directly from the economic activity of the Community, makes budget more passive and still more oriented towards its redistributive function.

However, the Commission proposals to widen the variety of own resources is being confronted by strong opposition. Therefore, other means are searched for as to achieve still the same goal, i.e. to deepen the integration of the national economies of the EU member states. These other means are the coordination of national economic policies and harmonization of their separate components.

Again, the significance of the EU budget is sometimes overestimated; its huge impact on agricultural production and farmers' income, without any good

\footnotetext{
${ }^{2}$ The so called traditional, own, resources consist of customs revenue, agricultural levies, and the sugar levy; two other types of own resources are the one based on value added-tax and another one based on gross national income (GNI) and calculated as a residual value, i.e. as the amount, needed to cover all agreed expenses of the EU budget, not funded by the means provided by the all the other own resources. Total amount of all budgetary expenses should not exceed 1.24 percent of GNI (Overview of the own resources system, http://europe.eu.int/comm/budget/financing/index_en.htm). Some time ago the upper limit of budgetary expenses was defined as 1.27 percent of the gross domestic product (GDP). According to the Decision of the Council and Euratom 2000/597/EU, Euratom GNI is gross national product of the current year. The Commission by its Communication of 28 December 2001 informed that due to the switchover from GDP to GNI the adjustment of the upper limit of the own resources was accomplished - 1.27 percent of GDP was recalculated as being 1.24 percent of GNI. The figure has decreased because capital outflows from the EU exceed its inflows, resulting in its GNI being larger than its GDP (net capital earnings abroad, repatriated to the EU, make the extra national income) and, therefore, the defined sum of own resources is represented by a respectively lesser share in GNI.

${ }^{3}$ In $2004 \mathrm{~m}$. the contribution calculated as a share of GNI made up 73.4 percent of all EU budget revenues, while the share of the revenue based on VAT provided 14.1 percent. (European Commission. MEMO/04/30. Brussels, 10 February 2004).

${ }^{4}$ European Commission. "Agenda 2000. For a stronger and wider Union”, Bulletin of the European Union. Supplement 5/97. Luxembourg, 1997, p. 67. Later the Commission tried to raise the question about creating an own resource in the form of a special Community tax on energy resources using ("energy tax"). Recently the Commission made a proposal to establish a European tax as an independent direct source of the EU budget revenues once again, by presenting draft new financial perspective (Thatcher's rebate haunts EU's 2007-2013 budget plans, www.euractiv.com, 1507 2004).
} 
reason, is passed over to the other fields of economic and social life, although budget possibilities there are very small. It is determined by its relative size that the EU budget has not to trespass the limit of 1.27 percent of the total EU GDG (1.24 percent of GNI). In practice, this ceiling is never achieved (for example in 2005 only 0.95 percent of GNI was made in for payments). For the sake of comparison it is to be observed that the budget of almost every developed country exceeds 40 , sometimes even 50 percent of its GNI. ${ }^{5}$

Why, in principle, is there any need to centralize a portion of public funds in federalist (including quasi-federalist) structures? As the theory of fiscal federalism states, the criterion of optimality of funds (and expenses) concentration at the central (federal) government level is the adequacy, by kind and amount, of public goods provided to tax payers for the needs and preferences of them.

Specifically, centralization of the budgetary revenues and expenses might be supported by the following arguments:

- Economy of scale and scope in providing public goods or services which means that in this case every unit of such a good (services) is cheaper and requires less inputs for its production;

- Centralization pools and disperses risks, which exist due to the asymmetry in the demand cycle of such services;

- Public goods are characterised by non-excludability, which means that supply will be insufficient if delivered in decentralized way;

- Decentralised provision of public goods might cause negative (or positive) externalities to the other administrative territories of the "federation";

- Duplication is avoided;

- Negotiating power increases. ${ }^{6}$

Economic integration is, first of all, liberalization of economic activity on the international scale within some territorial region. It raises the economic efficiency and welfare of every participant. It is considered that every citizen in the European Union, thanks to economic integration, has their income 10 percent higher than it would be without the EU.? Therefore, there is no reason even to start raising questions about the rationality of contributions dedicated to support (deepen) economic integration. If there would be no policy of income redistribution in the Community arena and the contributions of the member states would be restricted by sums, necessary to finance the administration of the EU, then the benefits of being in the Union would be absolutely obvious and nobody would question neither the necessity of such contributions, nor their amount. The situation is different when the full value of the "surplus" part of the contributions is given back to the members of the community.

\footnotetext{
${ }^{5}$ In 2004 the average public expenses in the OECD countries was 40.8 percent, among them in Sweden 57.1 percent, Denmark - 56.3 percent, Finland - 50.7 percent. (European Policy Centre. Growth and Jobs. September 2005, p.41).

${ }^{6}$ Iain Begg. Funding the European Union. A Federal Trust Report on the European Union`s Budget. London, March 2005, p. 19.

${ }^{7}$ George Gelauff, Herman Stolwijk, Paul Veenendaal. Europe's financial perspectives in perspective. European Network of Economic Policy Research Institutes. Working Paper No. 46, April 2006, p. 3.
} 
The EU budget is bigger then is needed to maintain the administration. While the Community does not conduct any stabilization policy by means of excessive or deficit budgeting, its budget makes an impact on the economy by its allocative actions in several chosen sectors and also indirectly by its redistributive policy implemented throughout some long sequences. Only some 5 - 6 percent of funds are used to finance the functioning of the EU institutions, the rest comes back to the member states; but their addressees are different and the fields of activity chosen to be financed are narrowly defined.

This domination of the passive redistributive function of the EU budget eventually turned up its shadowy side - it has developed an exclusively "trade-off" approach, a nurtured view of "just return" to the formation, and the distribution of the budget has weakened its original purpose and meaning. ${ }^{8}$ Besides, the budget structure also came to be obsolete, irrelevant, and rising dissatisfaction with it also strengthens differentiation on the views of the budget formation. The budget became a serious subject of content and it stimulates back-door factional fighting, it also suppresses the idea of solidarity, which was laid down in its nature. "...no voice will defend overall EU interests. For any individual country the return from defending an EU-wide, encompassing interest is negligible compared to the advantage it can obtain from a change in the budget that might lead to lower overall efficiency, but to more money for its own citizens or regional governments." 9

\section{The Budgetary Framework for 2007-2013: A Road to Agreement}

A switchover to a more perspective planning of the EU contributions and expenses was accomplished in 1980's when difficulties for countries to agree on a yearly EU budgetary plan arose. With the beginning of the implementation of the Single Market Programme the need emerged to have a multi-year budgetary perspective, defined and also known in size and structure, in advance. First such a financial perspective (Delors I package) was prepared exactly for the period of the Single Market Programme implementation, i.e. year 1988-1992. Other framework plans turned to the seven-year period: they were so-called Delors II package, which was basically devoted to financing actions necessary to achieve goals put in the Maastricht Treaty (1993-1999) and "Agenda 2000" (2000-2006) oriented towards the coming EU enlargement.

\footnotetext{
${ }^{8}$ The domination of the barter-type approach, which will eventually entrenched itself in the process of the EU budget formation has overshadowed the real meaning of income redistribution within the Community to assist lagging EU countries (partners) to raise their economic potential and to prevent the emergence of a "race to the bottom" in the sphere of social protection. (Žr. Sara Conolly, Alistair Munro. Economics of the Public Sector, Prentice Hall Europe, 1999, p. 498).

${ }^{9}$ D.Gros and S.Mikosi. A better budget for the European Union: More value for money, more money for value. CEPS Policy Brief, No. 66, Brussels, 2005, p.1.
} 
A new draft financial perspective was prepared by the Commission also for a seven-year period, although it has had stated that a period of five years, which matches the European Parliament's and the Commission's terms, would be preferable. The European Parliament, when discussing the FP guidelines, also expressed itself as being in favour of a five year horizon. ${ }^{10}$ The reason for declining these changes was that one of the main budget expense articles (the biggest one by its share) was already determined by the German-French agreement (October 2002), which was not to reduce (not to raise as well, while the EU widens) the amount of the Community funds directed to agriculture by the means of Common Agricultural Policy (CAP) until 2013 (to retain them unchanging in absolute amount approximately of 45 billion Euro). ${ }^{11}$ It is commonly admitted that Germany has agreed with this demand of France in exchange for the latter's agreement not to object to the EU Eastern European enlargement, which at that time was the main geopolitical interest of Germany. In December 2003, in Copenhagen, European Council member states came to common conclusions that they will return to the CAP reform in 2013.

An agreement between Chirac and Schröder on the funds provided to agricultural sector became a go-ahead sign for the member state's initiatives presented during the preparation of the new seven-year financial framework. The first official proposal directly targeting the framework was the statement issued by six member states, the largest net contributors (Germany, Austria, France, The Netherlands, Sweden and United Kingdom), requiring a reduction of the total EU budget amount down to 1 percent of GNI, issued in December 2003 (right after the failure of Intergovernmental Conference, which was held to approve the draft Constitutional Treaty).

The official debate on the new financial perspective that the Commission started in February 2004 through the Communication, "A prosperous Europe: political timetable and budgetary resources for an enlarged EU, 2007-2013" (later renamed to "Building our common Future: Policy challenges and Budgetary means of the Enlarged Union 2007-2013"), this emphasizing the need to implement the goals defined in the Treaty of the European Union. The Commission then drafted the budget, which during the seven-years period would require from the member states (EU-15) 1.22 percent GNI on average (with the share of the budget rising from 1.17 percent in 2007 to 1.24 percent in 2013). Having thess expenses recalculated for the EU, now enlarged to 27 member states, would mean that the outlays would reach just 1.15 percent in 2013 and would equal 1.14 percent on average throughout the period. ${ }^{12}$

\footnotetext{
${ }^{10}$ The necessity to switch to the five-year cycle, according to the EC statement, is based on the endeavouring need that future financial frameworks "...should become more consistent with this institutional rhythm [defined by the terms of the EC and EP - J.Č.]", Communication from the Commission to the Council and the European Parliament. Building our common Future: Policy challenges and Budgetary means of the Enlarged Union 2007-2013. Brussels, 26.2.2004. COM(2004) 101 final/2, p. 34.

${ }^{11}$ The return of Franco-German dominance? By Charles Grant, CER Bulletin, Issue 28. February/March 2003. - http://www.cer.org.uk/articles/28 grant.html.

${ }^{12}$ European Commission. IP/04/189. Building our common future: Financial and political outlooks for the enlarged Union 2007-2013. Brussels, 10 February 2004.
} 
The Commission pointed out that, although the Community is confronted by new tasks and it has considerably enlarged, there is no increase to the maximum amount of contributions (1.24 percent of GNI). But quite an arduous debate evolved not about the need to raise the upper limit of contributions, but about the requirement to reduce it. Although there were no direct references to the disagreement on it and the failure of the draft "EU Constitution," delivered by the Convention, the parallel was obvious - in both cases attempts to strengthen federal elements in the functioning of the Community met fierce opposition.

The Commission stressed in its Communication that, "The gap between the ambitious, highest-level political commitments, and a failure to implement them cannot be allowed to grow any wider." The goals and expectations of the Union should be supported by adequate resources. ${ }^{13}$

The goals of the Union for the planned period were formulated by the Commission in four directions: sustainable economic growth, preservation and management of natural resources, issues of citizenship, freedom, security and justice, and also the role of the EU as a global partner.

By suggesting to actually maintain the all existing structure of major expenses, the Commission also proposed to rearrange to some extent the proportions of different expenses, raising them in the areas important for the Union's economic growth and development. For instance, expenses for agriculture (both as direct payments and for rural development), hidden under a rather sophisticated heading "Preservation and management of natural resources," were defined not rising indeed - beginning from 2008 (in 2007 they still would be 57 billion Euro) up to 2013 they would remain the same amount, 58 billion Euro (in them direct payments for farmers and funds for agricultural product market regulation would even shrink a little bit - from 43.5 billion to 42.3 billion Euro). Meanwhile funds dedicated for the competitiveness and growth, and in order to sustain the rise of output and employment, would increase from 12 billion in 2007 to 26 billion Euro in 2013 (through the means financed by the European Social Fund and the Cohesion Fund). The Commission also envisaged more than double the finances directed to the heading "Citizenship, freedom, security and justice" - actually to fund expenses linked with the strengthening of external borders and the already being implemented common asylum and immigration policy and enhancing internal security (from 1.6 billion in 2007 to 3.6 billion Euro in 2013). The third purpose, "The EU as a global partner", „was also assigned a significant 38 percent raise in finances - from 11.4 billion in 2007 to 15.7 billion Euro in 2013". The main factor of the changes was the EU enlargement, resulting in an extension of the Community by countries of lesser level of economic development. Neither of them could become a donor country, meanwhile their eligibility to receive according to the rules agricultural payments, and the assistance from Cohesion Fund, as well as for protection of the new EU border was very intensive and accentuated.

\footnotetext{
${ }^{13}$ Communication from the Commission to the Council and the European Parliament. Building our common Future. Policy challenges and budgetary means of the Enlarged Union 2007-2013. Brussels, 10.2.2004, $\operatorname{COM}(2004) 101$ final, p.6.
} 
Already in 1997 the Commission, presenting draft "Agenda 2000," has demonstrated its farsightedness pointing out that "the next enlargement, which will take place during the period covered by the next financial perspective, will inevitably provoke a deterioration in the budgetary positions of all the current Member States. This cannot come as a surprise and should not give rise to claims for compensation."14

The publication of the new draft financial perspective just fuelled demands for compensation of contributions - not by giving them back through rising payments from the EU budget to donor countries, but by requirements to reduce their total amounts. The demand of the six net contributors to reduce the Community budget expenses to the limit of 1 percent of GNI, mentioned above, has drawn a new line which is a significantly lower line of solidarity and financial assistance directed to the less developed Community regions. The European Parliament stood against this position as well. Although its actual composition, with the new EP elections coming, did not take the job of thorough investigation of the budget structure, it nevertheless found reasonable (in April 2004) to observe that the requirement of the "six" is not well grounded. Countries of the "six" maintained that the EU should reduce its budgetary expenses since already many of these member states cannot hold expenses of their own national budgets, surpassing the threshold of the 3 percent of the GDP budget deficit. Regarding this, the EP noticed that in the period of 1996-2002 the EU budget rose by 8.2 percent while national budgets swelled by 22.9 percent on average. Therefore the increase in the EU budget expenses, by coming closer to the established limit, would have a minor impact on national budgets, since their deficits according to the figures just quoted, emerged or increased mainly due to the rise of domestic expenses and not because of the rising contributions to the EU budget)..$^{15}$

An important subject of contention came to be the partial refunding of the UK contributions (rebate). In 1984, yielding to the UK requirement, the European Council made the decision to adjust contributions to every member state which, "experiences excessive, in comparison to its relative well-being, a budgetary burden." The UK at that period was indeed a relatively less wealthy country (numbering fourth from the bottom in the then EU-12)..$^{16}$ The situation in the UK has changed later on and it overtook other large EU countries by GDP

\footnotetext{
${ }^{14}$ European Commission. Agenda 2000. For a stronger and wider Union, Bulletin of the European Union. Supplement 5/97. Luxembourg, 1997, p. 68.

${ }^{15}$ See: Parliament adopts guidelines for 2007-2013 financial perspective, www.euractive.com, 26042004. Some economic sense is contained and another argument, unofficially held by Germany, does contain some economic sense: the suggestion is not to include member states contributions to the EU budget when national budget deficit is calculated by monitoring implementation of commitments after Stability and Growth Pact. (See: "Najlepsze porozumienie juź w czerwcu", Rzeczpospolita, 1403 2005). Since these contributions go to the Community budget, their deficit (that is, inflation generating) origin is tempered to the extent which the rest of countries do not experience problems arriving at the balanced budget. However, if this would be the way the all member states escape the budget deficit problem, the idea would turn to be senseless because the entire eurozone would risk becoming an offender of the Stability and Growth Pact and would seriously destabilize the economy.

${ }^{16}$ See: www.euobserver.com, 16062005.
} 
per capita as well. ${ }^{17}$ The provision that the rebate is given temporary, and has to be reviewed, existed all the time. In 1997 the Commission, preparing new draft FP "Agenda 2000," made a remark that only "uncertainties surrounding the future relative prosperity situation of the United Kingdom, however, lead the Commission to propose postponing a re-examination of the rebate mechanism until immediately after the first enlargement." 18

It was stated that the political decision on the new FP should be made not later than June 2005; this was required by the necessity to conduct all preparations for the new budgetary period (according to the Commission, the work needed 12 to 18 months). With June approaching it became clear that advocates of alternative proposals of contributions being limited by 1 percent GNI or 1.14 percent of GNI are not ready to come to a quick agreement. This threatened support receiving countries by significant losses. It is enough to observe that without approval of a new multi-year financial framework, financing in the new period would be conducted according to the yearly expenses in the previous period (every month delivering one twelfth of funds), and the actual expenses are always less than appropriations for commitments. Besides, the previous budget (for the period 2000-2006) did not fully reflect the following EU enlargement, therefore its automatic continuation to the new budgetary period also would mean that less amount of funding would be delivered to the new member states.

The Temporary Parliamentary Committee prepared a report on the financial perspectives including a proposition to set the limit for the expenses of the new EU budget for the new period as 1.07 percent of $\mathrm{GNI} .{ }^{19}$ If compared to the EC draft, it suggested a reduction of funds in the field of agriculture and administration.

The Commission tried once again (at the beginning of June 2005) to convince member states, that a 1 percent ceiling, proposed by the "six," was unacceptable. If we are to maintain a CAP and cohesion policy, the EC wrote in its official document, then we shall have to sacrifice many measures that we are committed to implementing by realising the Lisbon strategy. But if we want to accelerate the EU's economic growth and strengthen its competitiveness, then we shall have to review a new agreement on the CAP and to change the basics of the cohesion policy, which will unavoidably trigger protests of many member states. The CAP, as the Commission conceded, is the element which splits the unity of the countries and stirs up their intransigence most powerfully. ${ }^{20}$

During the first half of 2005, Luxembourg, holding the presidency of the EU, prepared a compromise. It proposed to reduce the commitment ap-

\footnotetext{
${ }^{17}$ According to preliminary data, in 2005 the GDP per capita in PPS in the UK was 115 percent of the EU-25 average, while in Germany it was 110, in France - 109 per cent. (Eurostat news release, 79/2006, 15 June 2006).

${ }^{18}$ See: European Commission. "Agenda 2000. For a stronger and wider Union", Bulletin of the European Union, Supplement 5/97. Luxembourg, 1997, p. 68. EC made the proposal to establish a standard adjustment mechanism, according to which each member state will be regarded as over-paying if its net contribution to the EU budget would make up more than 0,35 per cent of its GNI; in this case it will be repaid 66 per cent of overpayment, but the total amount of rebate should not exceed 7,5 billion Euro per year. (See: Thatcher's rebate haunts EU's 2007-2013 budget plans, www.euractiv.com, 1607 2004). However, the proposal was eventually rejected.

${ }^{19}$ Žr. EP committee wants $1.07 \%$ spending cap for 2007-2013, www.euractiv.com, 12052005.

${ }^{20}$ See: "Financial perspective - why $1 \%$ is unrealistic", http://ec.europa.eu/financial perspective/pdf/why arguments.pdf\#search=\%22financial $\% 20$ perspective $\% 20-\% 20$ why $\% 201 \% 25 \% 20$ is $\% 20$ unrealistic $\% 22$.
} 
propriations to 1,06 per cent of the EU GNI, and payment appropriations to 1.00 percent. $^{21}$

The European Council's meeting in Brussels in June disapproved the proposal. It concluded that no agreement has been achieved. Like in 1999, in Berlin, the European Council discussed the previous financial perspective for 2000-2006 and the threat arose that with approval of a new budgetary framework coming too late, then the whole process of economic and political integration will suffer a serious setback.

The member states were left with the last opportunity - to come to an agreement at the European Council in December. As the Presidency of the EU now went to the hands of the UK, all the initiative was delivered to it.

One of the biggest reserves to reduce expenses was the UK rebate. The pressure to reduce it, the UK made dependent, as it used to be in intergovernmental bargaining, on the requirement to review the whole structure of financial perspective, wherein it (and not only the UK) saw the CAP with its large budget share being the most requiring of reform. "...We will have to chart a new direction for the European Union budget to ensure that it can respond to the challenges of the $21^{\text {st }}$ Century. That requires establishing a clear timetable for a review covering all aspects of revenue and expenditure," declared Jack Straw, the UK minister of foreign affairs in his speech in the EP on 16 November. So belated a proposal to reconstruct the EP anew was profoundly unrealistic and there was a good reason to regard it as being a deliberate manoeuvre with the aim to secure the British rebate and leave it unchanged (and, in absolute terms, growing). ${ }^{22}$

The commissioner Dalia Grybauskaite, charged with the financial programming and budget, agreed with J. Straw in that "today's European budget is not a budget for the 21st Century," but strongly criticized the principle British attitude to receive a fair return from the contributions, which for the Prime Minister Margaret Thatcher was the main argument to require her "money back." This British invention, D. Grybauskaite underlined, historically brought in "a poisonous element into the financial discussions." ${ }^{23}$

The situation was to be rescued as it used to be, when two very different views confronted one another and when the clash takes place in the EU, which is experienced in regulation such clashes, to search for some compromise.

The British position was more beneficial. They have been feeling some bitterness from the very moment of signing the Single European Act when they had to concede with the majority voting (instead of decision taking by consensus) on Single market issues. They looked suspiciously to many steps in the EU towards furthering integration (even in the economic area) thereby the threat for the deepening of the EU integration, which now has arisen, scared them less than their partners.

\footnotetext{
${ }^{21}$ See: Financial perspective 2007-2013. Negotiating box, Council of the European Union. Brussels, 15 June 2005. 10090/05.

${ }^{22}$ In 2005 the rebate amounted to 4.6 billion Euros. With the EU budget revenues and expenses rising due to the economic growth this sum would increase to 7 billion Euros, See: EU budget explains, www.euobserver. com, 16062005 .

${ }^{23}$ Grybauskaite: "Today's budget is not a budget for the 21st Century, www.euractive.com, 03082005.
} 
Having resolutely objected to the Luxembourg compromise in June, the UK was preparing its own proposals until as late as December. When at the end of November the first information on the British proposal was leaked to the press it became clear that the amount of budget will be suggested for further reduction, if compared to the Luxembourg compromise (not to speak about the EP and Commission proposals). The very delay to publish own propositions was a tactical manoeuvre aimed to provide less space for the searching and presentation of new propositions (The British also used this period for the very active diplomatic activity in order to gain wider support to their attitude).

The main British target was the CAP and the funds dedicated to it; the UK justly considered France as being the principal supporter and advocate of the CAP. Therefore the essence of its tactics was to encounter the French position and to prove that it obstructs the EU's efforts to achieve progress and precludes it to come to an agreement on the global scale. In the Doha round negotiations (where stubborn EU opposition to further liberalization of agricultural trade has led to the halt of the whole process of negotiations) the UK blamed France with inflexibility. The British themselves declared that they would profoundly reform the rebate repayments if the CAP would also start to be reformed. Prime Minister T. Blair offered the new member states that he shall immediately surrender payment of the part of the rebate if they support the British stance. ${ }^{24}$

On 5 December 2005, the UK officially made its proposal - to reduce the Luxembourg compromise on the ceiling of the EU budgetary expenses from 1.06 percent to 1.03 percent GNI, thereby cutting away another 24 billion Euro (totalling the reduction to 178 billion Euro when compared with the original Commission's proposal, when the ceiling was to be 1.14 percent GNI). Since the outlay for agriculture was fixed by the 2002 agreement between Germany and France, the UK quite naturally turned to another heading of large expenses and regional policy measures dedicated to the less developed EU countries and first of all - for the new member states. The UK suggested a reduction of regional funds by 10 billion Euros (a further 7 billion would be cut from the agricultural expenses - and 2 billion from rural development).

Such UK propositions were met by vehement opposition and criticism. ${ }^{25}$ The British started quite irksome bargaining about the various relocation of tiny numbers simulating the search of compromise, but in fact striving to defend their own principal position and/or to force opponents to retreat from theirs. ${ }^{26}$

The European Council, meeting 15-16 December, was obliged to come

\footnotetext{
24 "Blair and Brown hatch plans to make France the EU villain". The Telegraph, 03122005.

${ }^{25}$ It seems that politicians from these countries become irritated by T. Blair's cynical phrase that payments to assist new member states shall be reduced "by no more than 10 percent." (Financial Times 5.12.2005. Quoted by R. G. Whitman, G. Thomas. Two cheers for the UK's Presidency, www.chathamhouse.org.uk, 16.12.2005.

${ }^{26}$ When immediately before the beginning of the European Council T. Blair acquainted the EU member states leaders with the British proposal and the peers resolutely rejected the proposal. The British then managed to deliver another draft budget - adding to the previous sum of 847 billion Euro of total expenses a further 2.5 billion Euros (by this sum raising payments to the new member states which suffered a big reduction of support compared to the former British proposal). (See: "Blair promises third budget proposal", www. euobserver.com, 0512 2005). Finally bargaining started to become similar to a cheap farce. Actually, another version of the compromise began to emerge - to review the whole approved financial perspective in 2008.
} 
to an agreement on a new financial perspective. After serious blows to the EU unity, delivered by Common foreign and security policy (CFSP) crisis on the issue of Iraq intervention, rejections of the Constitutional Treaty, after shameful elections to the European Parliament, when only minority of the EU citizens came for voting ${ }^{27}$, inability to agree on new financial framework could be the last argument in proving that the EU entered the phase of its deep crisis, and has now to shelve the tasks of strengthening economic competitiveness and raising welfare. The agreement was achieved and the compromise found. The EU budget for the years 2007-2013 was increased to 1.045 percent of GNI (to the total sum of 862 billion Euros) mainly thanks to the mediation of German Bundeskanzlerin Angela Merkel (Germany agreed to reduce regional aid it receives) and the concessions of the UK (it consented with the reduction of the rebate by 10.5 billion Euros during 2009-2013 and to waive it beginning 2014) and France (it did not object to decision on substantial revision, in 2008, of the whole budgetary structure).$^{28}$ Pretty scared, the new member states accepted the subdued verdict.

Although the agreement removed the threat of a serious crisis, it has demonstrated the persistent significant differences in the economic interests in the "united Europe" and the political trajectories they determine, whenever periodical attempts to design common policies are undertaken. "Europe escaped paralysis," commented the agreement EK president Jose Manuel Barroso. "True, the European Commission wanted larger budget. However, the agreement of the 25 member states came to show what the political reality is. ${ }^{\prime 29}$ Commissionaire D. Grybauskaite resumed it in a similar way but more succinctly that, "Europe receives the budget it deserves." 30

The multilateral budgetary frameworks have not been established by the Rome Treaty, they therefore are approved according to the so-called Interinstitutional Agreement on Budgetary Discipline and Sound Financial Management. After the new framework has been elaborated in the Commission and approved in the Council, it was handed over to the European Parliament. The new financial framework has been discussed there over several months and the trilateral agreement was achieved on 4 April 2006. On 17 May, the Interinstitutional Agreement on the financial perspective 2007-2013 was signed and it came into force on 1 January 2007.

The EP succeeded in that, the final version of the FP took into account its requirements - the total sum of the budget expenses was increased to 864.3 billion Euros (thereby maximum appropriations for commitments rose from

\footnotetext{
${ }^{27}$ In the whole EU area the turnout in the EP elections was 45,7 per cent, and in the old member states (EU15) - 49,1 per cent, in new member states (EU-10) - 26 per cent (see Kenneth Chan. Central and Eastern Europe in the 2004 European Parliament Elections. A Not So European Event. - SEI Working Paper No.81, EPERN Working Paper No.16, p.5. - University of Sussex, 2004.

${ }^{28}$ See: W. Becker. EU summit reaches surprise agreement on budget for 2007-2013, www.dbresearch.com, December 22, 2005.

29 "Nowy budźet Unii: 60 mld zł rocznie dla Polski”, www.gazeta.pl, 18122005.

30 "Na jaki budźet zasluguje Europa", www.gazeta.pl, 20122005.
} 
$1.045 \%$ to $1.048 \% \mathrm{GNI}) .{ }^{31}$ Besides, it was concluded to detach budgetary components which amplify the budget's flexibility, while at the same time keeping their composition and governance in the competence of Inter-institutional Agreement. These autonomous components were the Emergency Aid Reserve, The EU Solidarity Fund, The Instrument of Flexibility, and the European Globalisation Adjustment Fund. ${ }^{32}$

The funds of the budget, when it is approved, will be used as it has also been up until now, in three main directions - to make a positive impact on the economic development, to provide for the EU citizen's security and other essential social needs, and to finance actions of the EU as a global actor.

Perhaps the most important correction in the use of expenses is a significant rise in attention for the strengthening of economic dynamism and competitiveness (heading 1 "Sustainable development"). Alongside routine directions of regional policy, and those financed from Cohesion fund (sub-heading $1 \mathrm{~b}$ "Cohesion for growth and employment"), a new accentuated direction was defined - "Competitiveness for growth and employment" (sub-heading $1 \mathrm{a}$, embracing Community funding for $\mathrm{R} \& \mathrm{D}$, innovations, education and training, EU-wide production networks, and social policy). In the new seven-year period, expenses for the needs of economic growth will increase from $51.3 \mathrm{bln}$. Euros in 2007 to 58.3 bln. Euros in 2013 (their share in the budget will grow from $42.5 \%$ to $45.9 \%$ ), in which expenses for competitiveness (sub-heading 1a) will rise from $8.4 \mathrm{bln}$. Euros (7.0 \%) to $13.0 \mathrm{bln}$. Euros (10.2 \% which is the largest rise in the share of expenses for the budget). Of course, expenses for traditional targets and infrastructural projects continue to dominate in absolute terms - in the seven year period $308 \mathrm{bln}$. Euros will be committed for them, meanwhile for the means committed for competitiveness growth $-74 \mathrm{bln}$. Euros.

Funding for agricultural needs is gradually receding. In the implementation of decisions brought in by the CAP review in 2003, and the agreement to freeze agricultural expenses until 2013, financing of agriculture and rural development $(80 \%$ of which are expenses for agricultural product market regulation and direct payments for farmers) will shrink from 55 bln. Euros in 2007 to 51.2 bln. Euros in 2013, thereby, alongside with some extension of the budget due to economic growth, their share in the whole budget will decline from $45.6 \%$ to $40.3 \%$.

Dynamics of the Community budget for the year 2007-2013 is also evidence that an increase of expenses (therefore also revenues as well) goes slower than that of the EU GNI. Therefore, appropriations for commitments will decline from $1.10 \% \mathrm{GNI}$ in 2007 to $1.01 \%$ GNI in 2013, and appropriations for payments, respectively, from $1.06 \%$ to $0.94 \% .{ }^{33}$ True, this change in share is calculated on the assumption that GNI of the EYU member states will grow

\footnotetext{
${ }^{31}$ EP warranted the increase of expenses by 2 billion. Euro in the sub-heading "Competitiveness for growth and employment"; in other fields of expenses it made only minor changes.

${ }^{32}$ See: A New Financial Framework for the enlarged Union (2007-2013), http://ec.europa.eu/budget/prior_future/next fin framework en.htm

${ }^{33}$ The whole data about budget figures - see: A new Financial Framework for the enlarged Union (20072013), http://ec.europa.eu/budget/prior_future/next_fin_framework_en.htm
} 
in this period by $2.3 \%$ on average. If the GNI will grow faster, the share of the Community budget expenses will decrease and if GNI will increase slower the movement will be the opposite.

\section{Some Results of "The European Union Case Study". What has been demonstrated by the discussion on the new financial perspective in 2004-2006?}

The investigation of the debate on the financial perspective for 2007-2013 is a kind of "EU Case Study." As with any kind of detailed budget activity, the FP reflects the main goals, priorities, comparable scale of directions chosen for actions, and also the interests of the members of that organization as when they search for an agreement, as well as the means they use in order to materialize them. The financial perspective, and debate on it, is to some extent a discussion on the perception of the EU and its further evolution, conducted up until the very end.

Perhaps, the main conclusion of such an investigation will be that the last EU enlargement, the incorporation to the Union of qualitatively less economically developed countries, disclosed both theoretical and political under preparedness of the "old" EU for the integration of countries being at some different level of development. The British rebate is one spectacular example of such under preparation -when some part of contributions of relatively poor post-communist countries to the EU budget are directed to the EU budget to improve the contributions and payments balance for a relatively prosperous country, the United Kingdom. ${ }^{34}$ One more example is the restriction of structural funds by 4 percent, of the recipient country GDP, which leads to the situation where significantly richer the member states, which continue to receive the EU financing in absolute terms per capita, are given larger assistance than those less wealthy. The third, even more conspicuous example is the convergence criteria that is to be fulfilled for joining the Economic and Monetary Union (EMU) and also for introducing the Euro in new member states. As the national economies of the EU member states function within the single market for goods, services, labour and capital, and the price level in new member states is twice lower than in EU-15 countries, the criterion requiring approximately the same inflation (price level rise) rate can not sustain any more serious criticism, and the requirement for new member states to be benchmarking their price level movement to that of countries with the least inflation rate (with just 1.5 percent adjustment upwards) provokes thoughts about theoretical incompetence. By

\footnotetext{
${ }^{34}$ In 2005, the GDP per capita in the UK was 115 percent of the EU average, meanwhile in Lithuania the indicator was 52 percent, Estonia - 57 percent, and the Czech Republic - 73 percent. - See: Eurostat News Release. 79/2006 15 June 2006.
} 
the way, some part of the criticism should be directed towards the new member states themselves - their academic and political elites are not fully ready professionally to investigate it and dull enough not to show it more emphatically.

Secondly, the discussion on a new financial perspective became an episode (not the first one), during which we see the recurrent tactical line of the member state's behaviour - in the periods of tension turn towards re-nationalisation of economic (not only) policy. One among such solutions was the CAP review, conducted in 2003, according to which the decoupling of farmers support from the amount of their production has started from 2005. Every year the direct support for farmers is reduced by 3 percent until it will decline by 20 percent, with the redirection of the saved funds to so-called second pillar of CAP i.e. assistance for rural development (and forestry). Since direct payments are fully financed from the EU budget, and rural development projects require 25 percent of national co-financing, this change is reasonably referred to as a move of re-nationalisation of the common policy for agriculture and rural development. Having in mind that richer EU member states have had more possibilities to co-finance rural development projects (therefore, to gain more Community funds for that purpose), such turn would in the same time mean the weakening of the essential goal of the Community budget - that of cohesion (not to mention distorting the impact on competition in the agricultural market). ${ }^{35}$ Of similar content is the more recent proposal by the Commission to increase national state aid for small and medium enterprises (according to it the upper limit for states subsidies would be raised from 100,000 Euros to 200,000 Euros). ${ }^{36}$ The EU budget, which can not come closer to the agreed upper limit, is the phenomenon of the same tendency.

Thirdly, on the macroeconomic (national) level the structural funds are earmarked for the reduction of economic and social differences between (small) countries and (in big member states) regions by using Community budget financing. But on the microeconomic level, assistance that is provided by structural funds becomes one more instrument in a national market by which those that have much receive the largest share of the assistance. The collapse of command economy and systemic changes experienced during these transformations, to the liberal market economy have caused a large increase in inequality in Lithuania, at a regional dimension as well. As research shows, in 1966 (when data on the district's economic and social development were first published) the difference between the richest district and the relatively poorest one in Lithuania was 60 percent, and in 2001 it differed 2.2 times. ${ }^{37}$ Government investment increases the difference even more, ${ }^{38}$ and the means provided by the EU structural funds, to the extent it can be judged on the beginnings of the

\footnotetext{
${ }^{35}$ Michael Halderman and Michael Nelson. EU Policy-Making: Reform of the CAP and EU Trade in Beef \& Dairy Sector with Developing Countries. PLPI Working Paper No.18. 25 January 2005, p.20, http://www. fao.org/AG/AGAInfo/projects/en/pplpi/docarc/wp18.pdf

${ }^{36}$ See: Commission to allow larger subsidies for SMEs, www.euractiv.com, 11.10.2006.

${ }^{37}$ Larry Sawers. "Inequality and the Transition: Regional Development in Lithuania", Baltic Journal of Economics, vol. 6, no. 1. Spring/Summer 2006, p.40.

${ }^{38}$ Ibid., p. 50.
} 
process and does not promise any evolution towards reductions of differences. Hence, structural funds do assist in raising the level of economic development in relatively lagging countries, but the progress inside countries (Lithuania) goes as a process of deepening the inequalities in a population's well-being and this makes people to question the mechanism and/or criteria of the use of incoming financial assistance. ${ }^{39}$

Fourthly, the domination of the redistributive function in today's EU budget divides (and shall divide - until the member states essentially will not differ among themselves by the level of their economic development) the member states into two camps of diverse interests. In one of them the donor countries and aid-receiving countries confront each other, in the second one countries receiving big sums for agricultural financing and those who actually finance this meet in the same antagonistic manner. The existence of the first camp, which in political rhetoric is explained and justified by the solidarity idea is basically a rational move. This policy, being implemented in an integrated entity, supports the states which have large growth potential with the result that their growth will support and stimulate dynamics in mature economies as well. This motive therefore raises less doubts.

On the contrary, the existence of the second camp is more controversial support of agriculture, especially by the existing measures has become questionable and if the very idea of support ("to preserve agriculture and rural life") might be acceptable for rather a significant number of member states, hardly fewer of them see irrationalities of the support mechanism. The CAP, as the political and legal basis for agricultural expenses in the EU budget, is now the closest subject for reforms. More so - by designing its reform - it would become possible (or necessary) to foresee the preliminary steps or versions for solutions of other tasks of the Union's economic development as well.

\footnotetext{
${ }^{39}$ This is not the only case, when the use of means of structural funds disavows the very purpose of these funds. The Commission still is preparing the rules, to be proposed at the end of 2006, according to which the information on the aid provided by implementation of CAP, shall compulsory be public. In several EU member states the community had expressed concern that huge funds go to big landowners who rent the land to farmers. Within the last two years the UK, the Netherlands, and Denmark made public the information about addressees of CAP money. The fact that the largest sums flow to the hands of royal families, ministers, international corporations, and other big landowners significantly undermined public trust in CAP. (See: "Brussels needs Finland in EU transparency push", http://www.euobserver.com, 21.09.2006).
} 


\section{Annex \\ Table 1. A comparison of the initial version of the financial perspective 2007-2013, presented by the Commission, and the final one, approved by the Inter-institutional Agreement, million Euros.}

\begin{tabular}{|c|c|c|c|c|c|c|c|c|}
\hline Appropriations & 2007 & 2008 & 2009 & 2010 & 2011 & 2012 & 2013 & Total \\
\hline \multicolumn{9}{|c|}{ Initial version } \\
\hline $\begin{array}{l}\text { Appropriations } \\
\text { for commitments }\end{array}$ & 1335,60 & 138,700 & 143,140 & 146,670 & 150,200 & 154,315 & 158,450 & $1,025,035$ \\
\hline Percent of GNI* & 1.23 & 1.25 & 1.25 & 1.26 & 1.26 & 1.27 & 1.27 & $\ldots$ \\
\hline $\begin{array}{l}\text { Appropriations } \\
\text { for payments }\end{array}$ & 124,600 & 136,500 & 127,700 & 126,000 & 132,400 & 138,400 & 143,100 & 928,700 \\
\hline Percent of GNI & 1.15 & 1.23 & 1.12 & 1.08 & 1.11 & 1.14 & 1.15 & 1.14 \\
\hline \multicolumn{9}{|c|}{ Final version } \\
\hline $\begin{array}{l}\text { Appropriations } \\
\text { for commitments }\end{array}$ & 120,702 & 121,473 & 122,564 & 122,952 & 124,007 & 125,527 & 127,091 & 864,316 \\
\hline Percent of GNI & 1.10 & 1.08 & 1.07 & 1.04 & 1.03 & 1.02 & 1.01 & 1.048 \\
\hline $\begin{array}{l}\text { Appropriations } \\
\text { for payments }\end{array}$ & 116,650 & 119,620 & 111,990 & 118,280 & 115,860 & 119,410 & 118,970 & 820,780 \\
\hline Percent of GNI & 1.06 & 1.06 & 0.97 & 1.00 & 0.96 & 0.97 & 0.94 & 1.00 \\
\hline
\end{tabular}

* The limit of 1.24 percent of GNI was calculated for the appropriations for payments. Recalculated as appropriations for commitments it made up 1.31 percent. (See New budget, old dilemmas. By Iain Begg and Friedrich Heinemann. - CER briefing note, 22 February 2006, p. 2.). Therefore appropriations for commitments are, in this table, larger than 1,24 percent of GNI, but they do not achieve 1,31 percent. Besides, as from 2008, the Commission has had foreseen the inclusion into the budget funds dedicated for the developmental needs of less developed countries (in the final version the idea was abandoned, the European Development Fund remained outside the EU budget).

Note: Yearly amounts of the budget are calculated on the assumption that real GDP of the Community will grow in average by 2.3 percent per year. - See www.eubusiness.com, 05 February 2004. Source: Data of the European Commission; author's own calculations.

\footnotetext{
The information on the aid provided by implementation of CAP, shall compulsory be public. In several EU member states the community had expressed concern that huge funds go to big landowners who rent the land to farmers. Within the last two years the UK, the Netherlands, and Denmark made public the information about addressees of CAP money. The fact that the largest sums flow to the hands of royal families, ministers, international corporations, and other big landowners significantly undermined public trust in CAP. (See: "Brussels needs Finland in EU transparency push", http://www.euobserver.com, 21.09.2006).
} 